\title{
Raízes históricas e atual missão do capelão naval Um estudo teológico-pastoral em perspectiva protestante
}

Orientador: Abimar Oliveira de Moraes

Mestrando: Israel Thiago Trota

Área de Concentração: Teologia Sistemático-Pastoral

Linha de Pesquisa: Fé e Cultura

Projeto de Pesquisa: Ministérios de serviço: identidade, missão e contribuições pastorais

A dissertação analisa o contexto histórico que marca a origem da função de capelão de navio no mundo; também procura refletir como esta tradição tornou-se comum nos navios brasileiros. Ao refletir sobre o nascedouro do capelão naval, a pesquisa analisa o perfil dos primeiros capelães navais e os desafios que envolveram os primórdios da assistência religiosa em uma embarcação. Por meio de pesquisa bibliográfica, mapeia a presença do capelão naval na historiografia brasileira e de sua Marinha, abarcando o desenvolvimento histórico nas fases da Colônia, Império e República, e da Marinha durante a Armada Real Portuguesa, na criação da Armada Imperial e Nacional, bem como na fase atual da Marinha do Brasil. Embora grande parte da pesquisa se suceda no campo da História, a motivação por trás da interpretação dos eventos é teológica e pastoral, promovendo uma interpretação protestante sobre a missão de um capelão naval na atualidade. A pesquisa reflete sobre a identidade do capelão naval, sua missão, seus desafios pastorais, os saberes que deve possuir e as atribuições deste ministério, revelando a necessidade de o capelão naval corresponder às exigências da instituição que representa, tendo a maturidade para pastorear um grupo heterogêneo e heterodoxo, dialogando com o ecumenismo e a inter-religiosidade, sem descaracterizar-se de sua confessionalidade. Impulsionado pelo desígnio de cumprir sua tríplice 
missão - assistência religiosa, assistência espiritual e apoio as atividades de educação moral - o capelão naval também é impelido teologicamente pela motivação cristã de servir as pessoas, testemunhando o evangelho de Cristo.

Palavras-chave: Capelão Naval Protestante. Serviço de Assistência Religiosa da Marinha do Brasil. Navio. Capelania. Teologia Pastoral. História do Capelão Naval. 